\title{
Research and Design of Shell Structure Resisting on Pile Foundation in Unstable Soil Condition using Etabs
}

\author{
V. Senthil Kumar, P. Swathika
}

\begin{abstract}
The software development block of G+7 has been considered to illustrate the analysis process. ETABS analysis tool is used for the analysis of the structure. This stud analyse and design the multi- story structure with shell element which is located at unstable ground condition (i.e.) the soil possess very low bearing capacity. As per standard code suitable pile foundation is designed for unstable ground condition. The whole structure with shell element and pile foundation is analysed and the results are consolidated. The essential parameters like structure stiffness, displacement, drift, shear, overturning moment are observed and plotted in graphs.
\end{abstract}

Keywords - Shell element, pile cap, Overturning moment, ETABS.

\section{INTRODUCTION}

In general, conventional frame design involves structural elements like column, slabs, beams. In flat slab system, the structural frame system consists of column and slab without beams. The slab load is transferred to the column directly due to absence of beams. The column is provided with drop and head. Floor-to-floor height can be deeply reduced and aesthetic view can be achieved by using flat slab construction. Flat slab makes us to provide Flexible room layout.

The shear wall resist the lateral load. Shear wall in high rise buildings is a preferable structural system to resist lateral loads due to wind load and seismic action. Wall position also influences the structural stability and stiffness of the structure. It can be provided at exterior as well as interior in both way directions.

\section{LITERATURE REVIEW}

Archa S Lal, et al - In this study, two load cases are considered axial compressive load and external pressure to design a shell structures. In which the shell structures waffle and iso-grids are designed using a modelling tool FEAST. On both structure, various analysis process like static analysis, buckling analysis and free vibration analysis are done using software tool FEAST. The results states that when compared to waffle shell structure buckling load factor for iso-grid structure is more and static displacement is less. The theoretical computation has also been made on buckling load factor for result comparison.

Thae Su Mon, et al - RC framed structure of G+20 storey is considered for this study. In which structural shear wall

Revised Manuscript Received on 14 August, 2019.

V. Senthil Kumar, Assistant Professor(SRG), Department of Civil, Kumaraguru College of Technology, Coimbatore, Tamilnadu, India.(Email:

P. Swathika, PG Student,Civil Engineering Department, Bannari Amman Institute of Technology, Sathymangalam, Erode, Tamilnadu, India. senthilkumar.v.ce@kct.ac.in)

system is implemented at various locations in the structures and 6 models were formed. As per UBC-97 various load conditions are considered like dead load, dead imposed load, live load, wind and seismic load and the structure analysed using a software tool called ETABS. To determine the effective use of shear wall at the structure. The displacement and storey drift could be reduced. The shear wall behaves effective when it is provided at both X \& Y- Direction.

Navyashree K, et al - Behaviour of Flat slab and RC Conventional structure were studied. The structural behaviour of the structure is observed and the results are given. The height of building influences the column behaviour. In which column designed for load combinations of dead load and seismic load. The period is more about 14$33 \%$ in flat structure than conventional building. About 28$57 \%$ of lateral displacement would vary between RC structure and flat plate structure.

Kaulkhere R.V, et al - The two cases have been designed manually and using software ETABS for G+8 storey building which possess square and rectangle flat slab. The results states that, the period value is not that much varied for both square and rectangular flat slab structures. The square slab building has higher base shear than the rectangular slab. When compared to square slab building the storey displacement of rectangle slab is higher.

\section{BUILDING MODELLING}

The software development block of G+7, RC framed structure with flat slab which is resisting on pile foundation is designed. ETABS software is used to create $3 \mathrm{D}$ model. With varying height of the column the model is developed. The building is considered to be rests on unstable soil condition.

\section{A. Specifications \\ - $\quad$ Number of stories: G.F+ 7 stories \\ - $\quad$ Stilt Height: $3.5 \mathrm{~m}$ \\ - $\quad$ Height of typical storey: $3.9 \mathrm{~m}$ \\ - Height of pile cap top: $8 \mathrm{~m}$ \\ - $\quad$ Beam size: $750 \mathrm{~mm} * 600 \mathrm{~mm}$ \\ - Column size: $750 \mathrm{~mm} * 750 \mathrm{~mm}$ \\ - Thickness of flat slab: $225 \mathrm{~mm}$ \\ - Thickness of drop: $450 \mathrm{~mm}$ \\ - $\quad$ Concrete Grade: M30, M50 \\ - $\quad$ Steel Grade: Fe 500 \\ - $\quad$ Soil type- loose soil (unstable)}

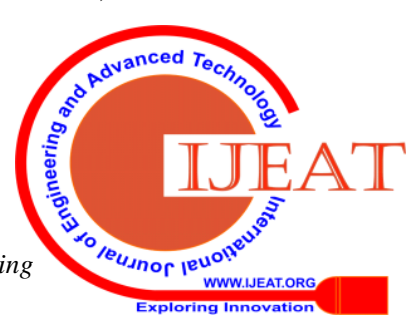


- $\quad$ Foundation type: Pile foundation

- Unit weight of brick wall : $20 \mathrm{kN} / \mathrm{m}$

\section{B. Load Type}

Various loads acting on the structure.(Dead load, Dead Imposed, Live, Wind and Seismic load).

1. Self-weight includes dead load of the column, beam and structural slab.

- $\quad$ Total Load $=460.23 * 10^{\wedge} 3 \mathrm{kN} / \mathrm{m} 3$

- $\quad$ Dead imposed load Wall load $=14 \mathrm{kN} / \mathrm{m} 3$.

2. Live load: $3 \mathrm{kN} / \mathrm{m} 2$

3. Seismic load: From code 1893 part 1: 2016

1. Seismic Zone: III, IV, V

2. Zone factor $(Z=0.16,0.24,0.36)$

3. Response reduction factor: 3

4.Importance factor: 1

5.Soil type: Loose soil

6.Damping Ratio: 5\%

\section{Load Definition}

TABLE I

\begin{tabular}{|l|l|}
\hline Name & Type \\
\hline Dead Load & Linear Static \\
\hline Dead Imposed & Linear Static \\
\hline Live & Linear Static \\
\hline Wind WLPX & Linear Static \\
\hline Wind WLPY & Linear Static \\
\hline Wind WLNX & Linear Static \\
\hline Wind WL NY & Linear Static \\
\hline SP & Response Spectrum \\
\hline
\end{tabular}

D. Storey Data

TABLE II

\begin{tabular}{|l|l|l|}
\hline Description & $\begin{array}{l}\text { Storey } \\
\text { Height } \\
(\mathbf{m})\end{array}$ & $\begin{array}{l}\text { Elevation in } \\
(\mathbf{m m})\end{array}$ \\
\hline Terrace floor & 3.85 & 40.95 \\
\hline Sixth floor & 3.9 & 37.1 \\
\hline Fifth floor & 3.9 & 33.2 \\
\hline Fourth floor & 3.9 & 29.3 \\
\hline Third floor & 3.9 & 25.4 \\
\hline Second floor & 3.9 & 21.5 \\
\hline First floor & 3.9 & 17.6 \\
\hline Stilt floor & 3.5 & 13.7 \\
\hline Grade slab & 2.2 & 10.2 \\
\hline Pile cap top & 8 & 8 \\
\hline Base & 0 & 0 \\
\hline
\end{tabular}

\section{E. Load Combinations}

From IS:1893 (Part I): 2016 Clause no. 6.3.1.2 The various load cases are considered.

COMB1 $=1.5(\mathrm{DL}+\mathrm{DIL}+\mathrm{LL} 1)$

$\mathrm{COMB} 2=1.5(\mathrm{DL}+\mathrm{LL} 1+\mathrm{LL} 2+\mathrm{DIL}+\mathrm{TL})$

$\mathrm{COMB} 3=1.2(\mathrm{DL}+\mathrm{DL}+\mathrm{DIL})+0.6 \mathrm{LL} 1+0.3 \mathrm{LL} 2+$ 1.2ELX

COMB4=1.2(DL+DL+DIL $)+0.6 \mathrm{LL} 1+0.3 \mathrm{LL} 2+1.2 \mathrm{ELY}$

$\mathrm{COMB} 5=1.5(\mathrm{DL}+\mathrm{DIL}+\mathrm{ELX})$

COMB6 $=1.5(\mathrm{DL}+\mathrm{DIL}+\mathrm{ELY})$

COMB7 $=0.9(\mathrm{DL}+\mathrm{DIL}+\mathrm{ELx})$

COMB8 $=0.9(\mathrm{DL}+\mathrm{DIL}+\mathrm{ELx})$
COMB9 $=1.2(\mathrm{DL}+\mathrm{DIL}+\mathrm{LL} 1+\mathrm{LL} 2+\mathrm{TL}+\mathrm{WLX})$

$\mathrm{COMB} 10=1.2(\mathrm{DL}+\mathrm{DIL}+\mathrm{LL} 1+\mathrm{LL} 2+\mathrm{TL}+\mathrm{WLX})$

$\mathrm{COMB} 11=1.2(\mathrm{DL}+\mathrm{DIL}+\mathrm{LL} 1+\mathrm{LL} 2+\mathrm{TL}+\mathrm{WLY})$

COMB12 $=1.2($ DL+DIL LL1 + LL2 + TL - WLY $)$

COMB13 $=1.5(\mathrm{DL}+\mathrm{DIL}+\mathrm{WLX})$

COMB14 $=1.5(\mathrm{DL}+\mathrm{DIL}-\mathrm{WLX})$

COMB15 $=1.5(\mathrm{DL}+\mathrm{DIL}+\mathrm{WLY})$

COMB16 $=1.5(\mathrm{DL}+\mathrm{DIL}-\mathrm{WLY})$

COMB17 $=0.9(\mathrm{DL}+\mathrm{DIL})+1.5 \mathrm{WLX}$

COMB18 $=0.9(\mathrm{DL}+\mathrm{DIL})-1.5 \mathrm{WLX}$

COMB19 $=0.9(\mathrm{DL}+\mathrm{DIL})+1.5 \mathrm{WLY}$

COMB20 $=0.9($ DL+DIL $)-1.5 \mathrm{WLY}$

F. Plan View

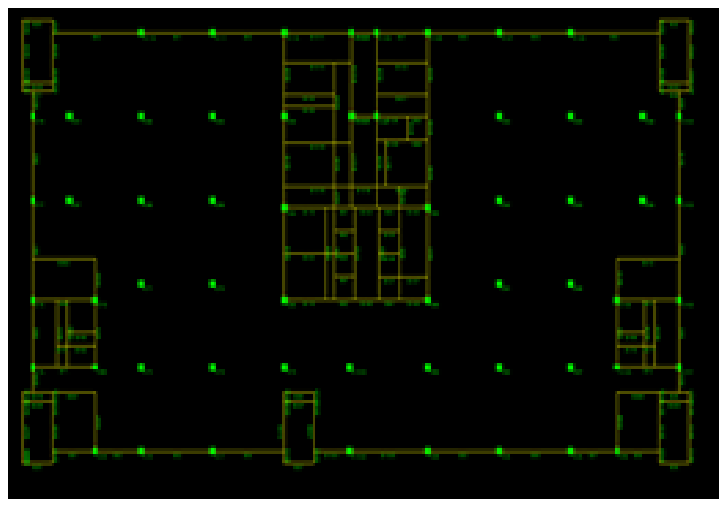

Fig 1: Plan view

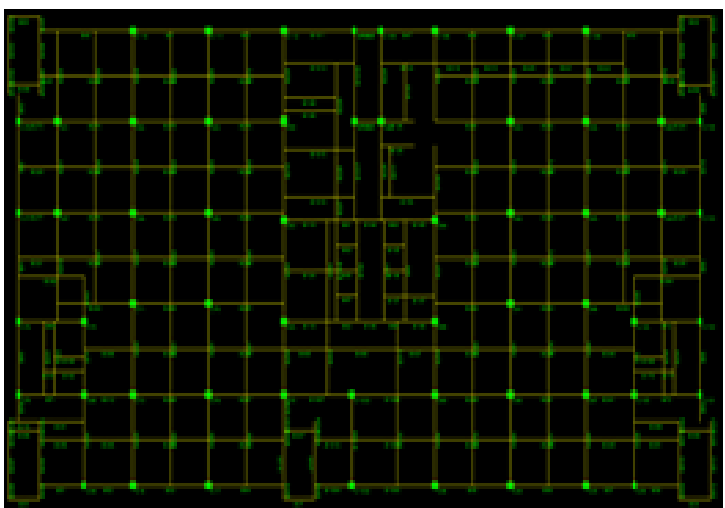

Fig 2: Plan - Grade slab

Plan view above base level and below base level is shown in the fig. 3

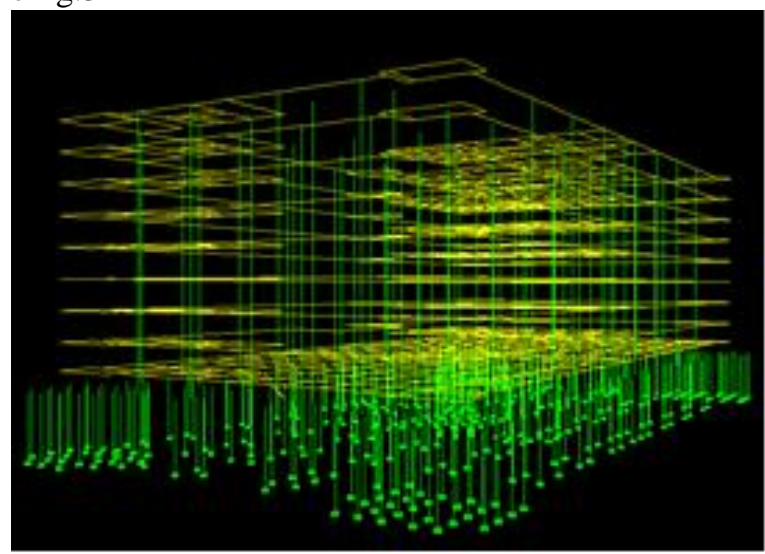

Fig 3: 3-D View of Structure

Published By: 


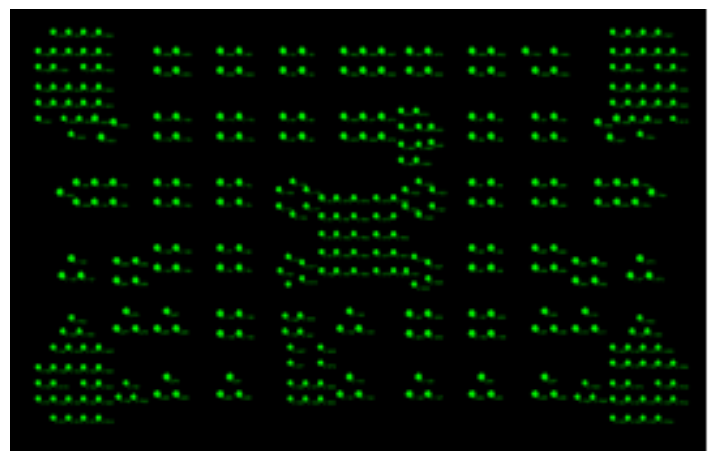

Fig 4: Plan view of Pile foundation fig. 4

Plan view of pile location of the structure is shown in the

\section{RESULTS AND DISCUSSIONS}

\section{A. Storey Displacement}

The maximum storey displacement graph of the structure which is shown against global $\mathrm{X} \&$ global $\mathrm{Y}$ taken from ETABS shown in Fig 5.

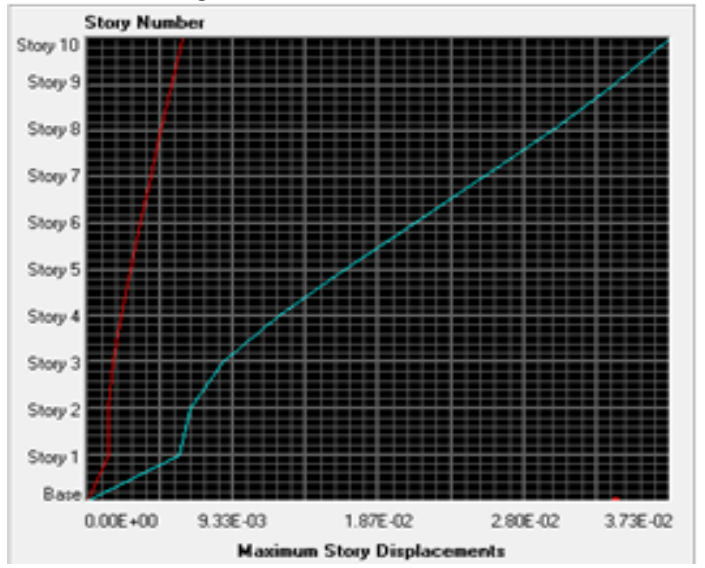

Fig 5: Maximum Storey Displacement

The displacement of the structure From fig 5. are maximum attop of the structure and minimum at base of the structure.

\section{B. Maximum Storey Drifts}

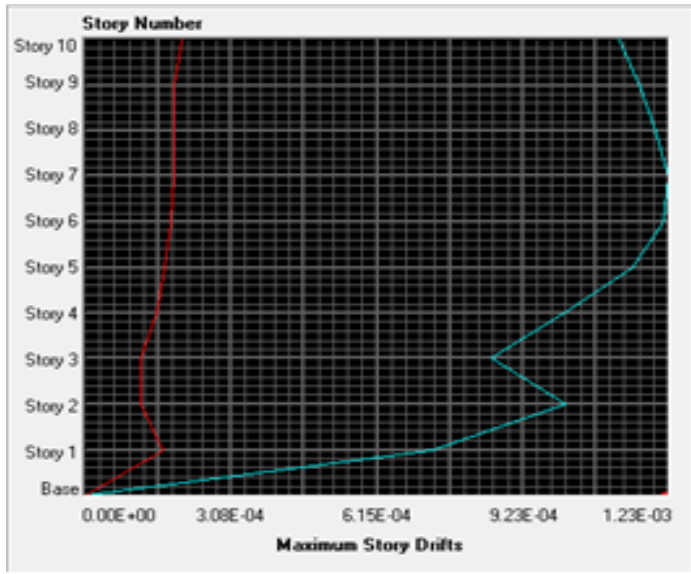

Fig 6: Maximum Storey Drift

Maximum storey drift graph Flat slab and RC framed structure from ETABS is shown in Fig 6. The drift of the structure is maximum at top of the structure and minimum at base of the structure.

\section{Storey Shear of Models}

The storey shear is shown in Fig 7, The storey shear in the building is due to lateral forces. It shows that for each storey changes from maximum at bottom to minimum at top of the structure.

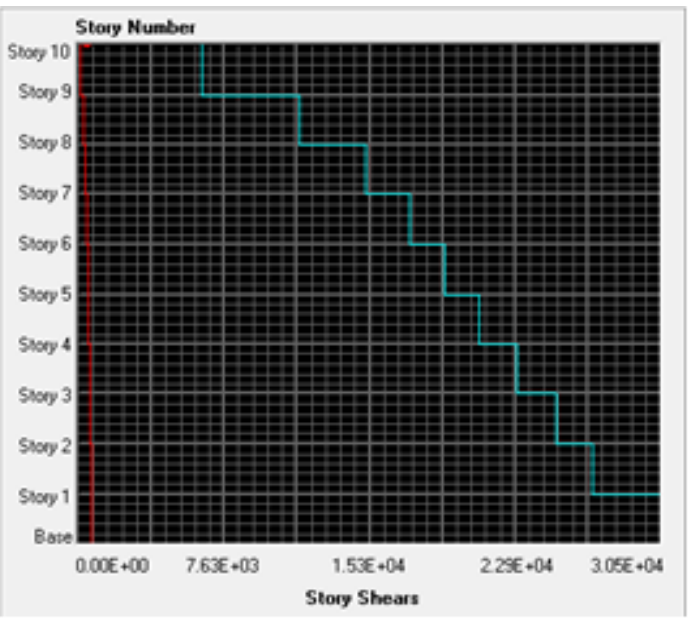

Fig. 7 Storey Shear

\section{Storey Overturning Moments of Models}

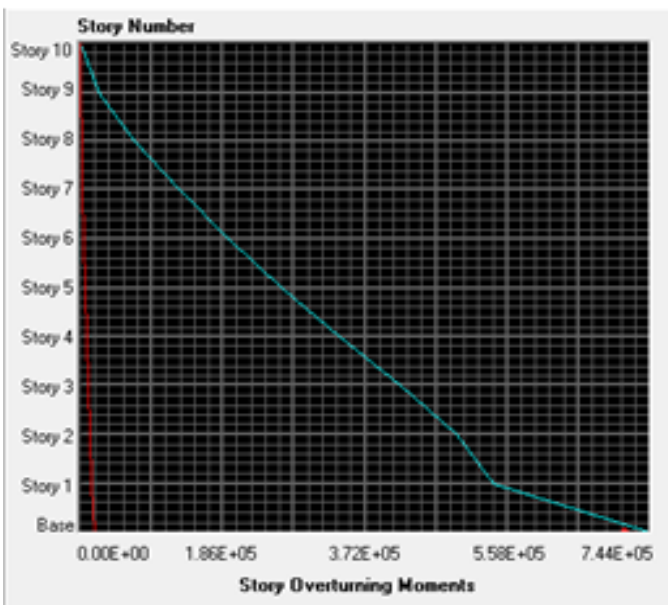

Fig. 8 Overturning Moments of Structure

Fig 8 shows the overturning momentsof the structure. The storey shear in the building is due to lateral forces and is calculated for each storey from maximum at bottom and minimum at top of the structure.

\section{E. Response Spectra Curve}

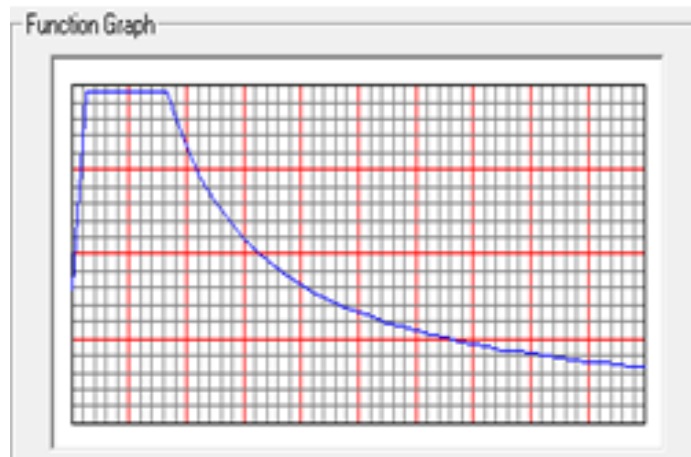

Fig. 9 Response Spectra curve
Blue Eyes Intelligence Engineering \& Sciences Publication

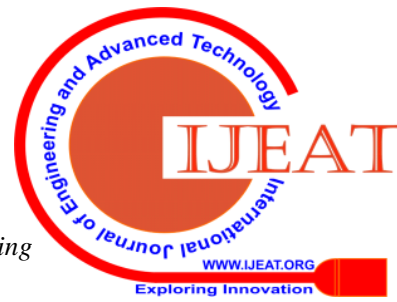


The response spectra curve is shown in fig 9. This curve is compared with standard spectral curve from IS 1893 part 1: 2016

\section{CONCLUSIONS}

Based on this model analysis,

By locating the shear wall at proper position the lateral loads can be reduced.

By providing pile foundation the unstable soil condition can be managed and stable foundation is provided for the structure. Thus the pile foundation is suitable for unstable soil condition.

It shows that the usage of flat slab makes us to provide flexible room layout. The column carries the entire load directly from the slab. Thus, it is economical to construct the structure without using beams.

The implementation of shell structure and shear wall system inthe structure is much effective due to reduction in displacement and drift.

\section{REFERENCES}

1. Archa S Lal, et al, "Design of Integrally Stiffened Shell Structures". International Research Journal of Engineering and Technology (IRJET), Volume: 04 Issue: 05, May -2017 e-ISSN: 2395-0056, P-ISSN: 2395-0072.

2. Navyashree K, et al, "use of flat slabs in multi-storey commercial building situated in high seismic zone" IJRET: International Journal of Research in Engineering and Technology, eISSN: 2319-1163 | pISSN: 2321-7308.

3. Kaulkhere R.V, et al, "Analysis and Design of Flat slab with various shapes" (c) May 2017 IJSDR | Volume 2, Issue 5, ISSN: 2455-2631.

4. Chandak N. R, "Effect of Base Isolation on the Response of Reinforced Concrete Building" Journal of Civil Engineering Research 2013, 3(4): 135-142, DOI: 10.5923/j.jce.20130304.02

5. Izuru Takewaki, et al, "Efficient analysis of pile-group effect on seismic stiffness and strength design of buildings" Soil Dynamics and Earthquake Engineering 25 (2005) 355-367, (C) 2005 Elsevier Ltd. All rights reserved.

6. Sanisha Santhosh, et al, "Seismic Analysis of Multi Storied Building with Shear Walls of Different Shapes" International Journal of Engineering Research \& Technology (IJERT), ISSN: 2278-0181, Vol. 6 Issue 06, June - 2017

7. Reeba Mary Cherian, et al, "Seismic Analysis of Multistoried Symmetrical Building Based on Shear Wall Positions" International Journal of Engineering Research \& Technology (IJERT), ISSN: 2278-0181 Vol. 6 Issue 06, June - 2017

8. G. Agarwal P and Shrikhande M - Earthquake Resistant Design of Structures, New Delhi, PHI learning Private Limited, 2015. 